\title{
Analisis Uji Validasi Buku Panduan Video Analisis pada Materi Kinematika untuk Calon Guru Fisika
}

\author{
Thoha Firdaus $^{1}$, Ida Hamidah ${ }^{2}$, Wawan Setiawan ${ }^{3}$, Ida Kaniawati ${ }^{4}$ \\ 1,2,3,4 Universitas Pendidikan Indonesia \\ Jl. Dr. Setiabudi No.229, Isola, Kec. Sukasari, Kota Bandung, Jawa Barat, 40154 \\ ${ }^{1}$ STKIP Nurul Huda \\ Jl. Kota Baru, Kec. Buay Madang, Kab. Ogan Komering Ulu Timur, Sumatera Selatan \\ *E-mail: thohaf@stkipnurulhuda.ac.id
}

\begin{abstract}
Abstrak
Telah dibuat panduan eksperimen video analisis pada materi kinematika menggunakan program logger pro untuk calon guru fisika. Penelitian ini bertujuan untuk melihat hasil kelayakan panduan eksperimen. Metode penelitian ini menggunakan design and development research (DDR). Panduan divalidasi oleh ahli pengguna dan ahli materi dengan nilai rata-rata yang dapat secara berurutan adalah $79,69 \%$ dan $87,5 \%$. Sehingga dapat disimpulkan bahwa panduan video analisis ini dapat diterima dan layak untuk dapat digunakan oleh calon guru fisika.
\end{abstract}

Kata kunci: Video analisis, panduan eksperimen, kinematika, logger pro.

\begin{abstract}
A video analysis experiment guide has been made on kinematics material using the pro logger program for prospective physics teachers. This study aims to see the results of the feasibility of an experimental guide. This research method uses design and development research (DDR). The guide is validated by user experts and material experts with an average value that can be sequentially $79.69 \%$ and $87.5 \%$. So it can be concluded that this video analysis guide is acceptable and feasible to be used by students.
\end{abstract}

Keywords: Video analysis, experimental guides, kinematics, pro loggers.

\section{PENDAHULUAN}

Pada masa sekarang, pembelajaran difokuskan dengan menyediakan fasilitas yang lengkap dan inovatif guna menarik perhatian siswa untuk belajar (Nursapikka, Daningsih, \& Yokhebed, 2017). Terkhusus untuk materi fisika yang pembelajarannya lebih kepada eksperimen. Fisika umumnya didasarkan pada pengamatan eksperimen dan pengukurannya berupa kuantitatif. Hukum dasar dinyatakan dalam bahasa matematika, yakni sebagai alat yang menyediakan jembatan antara teori dan eksperimen (Firdaus \& Sinensis, 2017). Fisika tidak hanya didasarkan kepada teori saja dan mengabaikan kegiatan eksperimen, dikarenakan pengetahuan fisika ditemukan dalam kehidupan sehari-hari. Belum lagi fisika umumnya diakui sebagai konseptual sulit karena pembelajaran fisika terdiri dari konsep- konsep yang berkaitan dengan kehidupan nyata (Firdaus, Setiawan, \& Hamidah, 2017).

Eksperimen tidak bisa hanya dilakukan tanpa adanya sebuah panduan petunjuk penggunaan. Ini akan mengakibatkan pembelajaran menjadi kacau dan konsep tidak dapat tersampaikan dengan baik. Seperti pengamatan yang dilakukan olah Suprianto, Kholida, \& Andi (2017) bahwa terdapat banyak mahasiswa yang kurang termotivasi dan mengalami kesulitan merangkai alat-alat praktikum, jarang bertanya, kurang kedisiplinan serta kelemahan soft skill lainnya.

Kinematika dalam pembelajaran fisika, merupakan materi dasar dan wajib dikuasai oleh mahasiswa. Dasar pemahaman konsep kinematika, akan berpengaruh kepada konsep materi fisika lainnya jika belum dikuasai dengan baik. Namun pada kenyataannya, dari hasil penelitian dan observasi (Firdaus \& Sinensis, 
2017) mahasiswa masih banyak yang belum memahami bentuk garis dan variabel dari grafik gerak lurus. Apalagi ketika variabel pada grafik di ganti, dan dengan soal yang sama mereka masih salah dalam memahami.

Logger Pro merupakan aplikasi premium analisis video yang mampu menampilkan gejala-gejala alam menjadi sebuah data yang dapat di olah dan dianalisis. Aplikasi ini selain digunakan untuk menganalisis gejala alam melalu video, juga didesain agar dapat dipasangkan pada berbagai sensor secara simultan. Perangkat dapat dihubungkan langsung dengan komputer sehingga data yang terekam mudah diolah oleh aplikasi (Lusiyana, Toifur, \& Rohman, 2012). Penggunaan Logger Pro yang dilakukan oleh (Milner-Bolotin \& Moll, 2008) telah sukses dijadikan sebuah pembelajaran laboratorium untuk pemecahan masalah kolaboratif. Jika proses pembelajaran dengan video analisis ini dapat diterapkan dengan baik, khususnya pada materi kinematika, maka seorang peserta didik nantinya akan mampu mempunyai kemampuan menganalisis dengan baik dan mampu memecahkan permasalahan dalam kehidupan sehari-hari. Untuk mendapatkan proses pembelajaran yang baik ini tidak terlepas bagaimana kualitas dari petunjuk panduan pembelajaran eksperimen yang baik.

\section{METODE}

Metode penelitian ini menggunakan design and development research (DDR). Metode ini pertama kali dikenalkan oleh Brown dan Collins pada tahun 1992 (Sahrir, Alias, Ismail, \& Osman, 2012). Ellis \& Levy (2010) mengembangkan desain dari Peffers, Tuunanen, Rothenberger, \& Chatterjee (2007) membagi enam fase langkah model desain dan pengembangan, seperti pada gambar 1 .

Secara sistematik penelitian dan pengembangan ini dilakukan melalui tahapantahapan berikut:

1. Identifikasi masalah, dimana ditemukan sebuah kasus di lapangan terkait pembelajaran kinematika yang berkaitan dengan pemahaman grafik, mahasiswa masih banyak yang belum memahami bentuk garis dan variabel dari grafik gerak lurus.

2. Menggambarkan tujuan, ini disusun berdasarkan bagaimana mengatasi masalah yang terjadi pada kasus di lapangan. Mahasiswa diharapkan dapat menganalisis fenomena fisika dalam kehidupan sehari-hari serta dapat mengembangkan kemampuan analisis, pemecahan masalah dan berpikir kreatif.

3. Desain dan pengembangan panduan, disusun dengan mempertimbangkan keberhasilan dan tercapainya tujuan dari panduan video analisis pada materi kinematika.

4. Melakukan pengujian petunjuk panduan penggunaan. Kegiatan ini dilakukan oleh beberapa validator, yang pertama adalah ahli pengguna yang berjumlah 10 validator yang dari mahasiswa di beberapa perguruan tinggi. Mahasiswa yang melakukan validator ini sudah pernah mempelajari dan melakukan uji coba program Logger Pro. Validator kedua adalah ahli materi, terdiri dari 3 dosen dari beberapa perguruan tinggi yang satu diantaranya adalah dosen juga seorang kepala laboratorium.

5. Metode analisis yang digunakan dalam penelitian ini menggunakan deskriptif kuantitatif menggunakan presentasi persamaan berikut:

$$
\begin{aligned}
& \%=\frac{\text { Nilai }}{\text { Jumlah skor ideal }} 100 \% \\
& \text { Keterangan } \% \text { nilai: } \\
& 81 \%-100 \% \text { = Sangat Baik } \\
& 61 \%-80 \% \text { =Baik } \\
& 41 \%-60 \%=\text { Cukup } \\
& 21 \%-40 \%=\text { Kurang } \\
& 0 \%-20 \% \text { = Sangat kurang }
\end{aligned}
$$

6. Evaluasi hasil pengujian, dilakukan setelah melakukan uji validasi petunjuk panduan eksperimen. Masukkan dari validator digunakan untuk melakukan evaluasi dan perbaikan petunjuk panduan.

7. Mengkomunikasikan hasil, setelah proses evaluasi selanjutnya panduan petunjuk dikomunikasikan untuk kemudian disebarluaskan. 


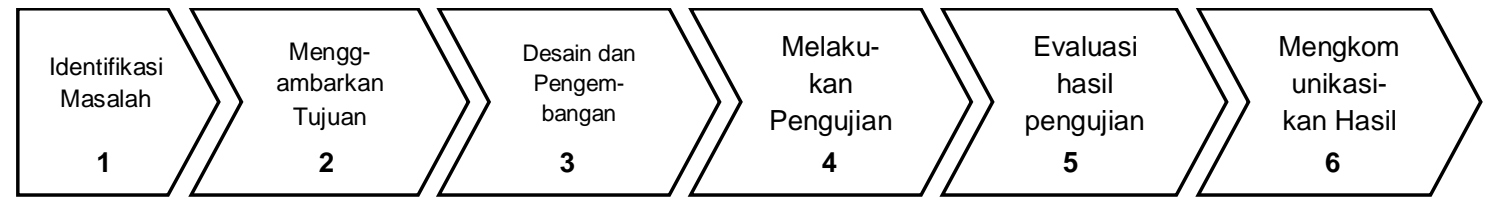

Gambar 1. Fase pendekatan desain dan pengembangan penelitian

\section{HASIL DAN PEMBAHASAN}

Telah dibuat petunjuk panduan penggunaan video analisis pada materi kinematika untuk calon guru fisika. Panduan eksperimen ini diberi judul dengan "Panduan Video Analisis Menggunakan Program Logger Pro". Panduan ini diharapkan mampu meningkatkan kemampuan kreativitas, analisis dan kemampuan pemecahan masalah mahasiswa dalam kehidupan sehari-hari. Buku petunjuk memuat identitas panduan, tujuan, alat dan bahan, langkah kerja (diantaranya panduan menganalisis video). Informasi penting terkait panduan video analisis seperti materi apa saja yang dapat mendukung serta kemampuan apa saja yang akan dimiliki mahasiswa ditampilkan di halaman cover dengan desain yang menggambarkan fenomena kinematika seperti gambar 2 .

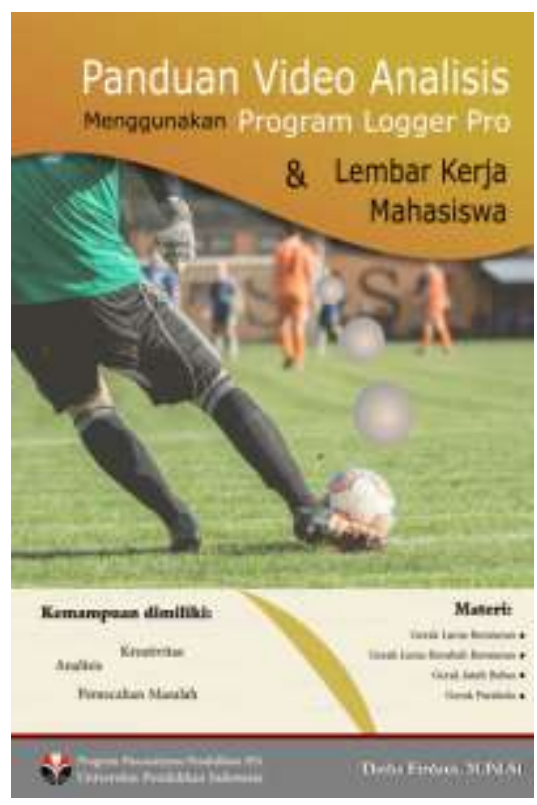

Gambar 2. Desain cover panduan video analisis menggunakan Logger Pro.
Hasil validasi untuk ahli pengguna dinilai dengan skala maksimal 4 dengan hasil sebagai mana tabel 1. Komponen penilaian berjumlah 8 poin, dengan rata-rata nilai yang dihasilkan berjumlah 3,19 atau dengan jumlah presentasi $79,69 \%$ dengan kriteria baik.

Tabel 1. Hasil penilaian panduan eksperimen untuk ahli pengguna

\begin{tabular}{|c|c|c|}
\hline Komponen Penilaian & Nilai & $\%$ \\
\hline $\begin{array}{l}\text { Penggunaan kaidah } \\
\text { bahasa } \\
\text { Pemahaman menelaah }\end{array}$ & 3,2 & 80 \\
\hline $\begin{array}{l}\text { Pemanaman menelaah } \\
\text { kalimat }\end{array}$ & 3 & 75 \\
\hline Kejelasan gambar & 3 & 75 \\
\hline $\begin{array}{l}\text { Petunjuk pada gambar } \\
\text { Prosedur yang perlu }\end{array}$ & 3,1 & 77,5 \\
\hline $\begin{array}{l}\text { dipersiapkan } \\
\text { Langkah ketentuan }\end{array}$ & 3,6 & 90 \\
\hline pengambilan video & 3 & 75 \\
\hline Urutan langkah-langkah & 3,4 & 85 \\
\hline Analisis grafik & 3,2 & 80 \\
\hline Rata-rata & 3,19 & 79,69 \\
\hline
\end{tabular}

Visual grafik hasil dari validasi panduan oleh ahli pengguna yang dilakukan oleh beberapa mahasiswa di beberapa perguruan tinggi sebagaimana pada gambar 3 .

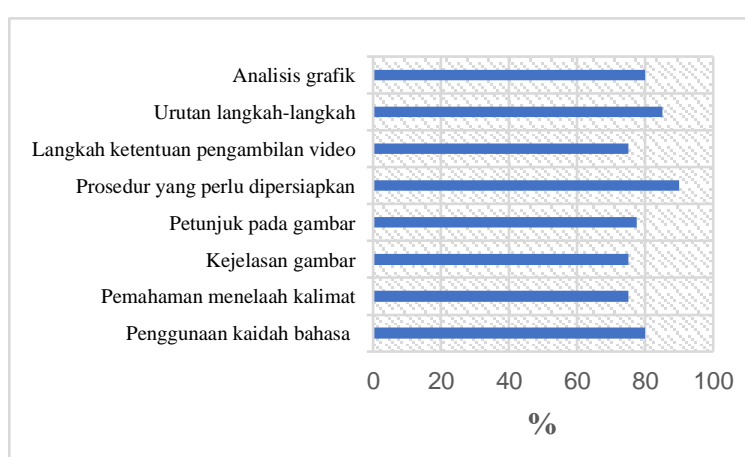

Gambar 3. Hasil validasi dari dari ahli pengguna

Sedangkan hasil validasi untuk ahli materi dinilai dengan skala maksimal 4 dengan 
hasil sebagai mana tabel 2. Komponen penilaian berjumlah 6 poin, dengan rata-rata nilai yang dihasilkan berjumlah 3,5 atau dengan jumlah presentasi $87,5 \%$ dengan kriteria sangat baik.

Tabel 2. Hasil penilaian panduan eksperimen untuk ahli materi

\begin{tabular}{lcc}
\hline Komponen penilaian & Nilai & $\%$ \\
\hline Identitas panduan & 3,67 & 91,67 \\
Tujuan & 3,33 & 83,33 \\
Alat dan Bahan & 3,67 & 91,67 \\
Langkah Kerja & 3,33 & 83,33 \\
Bahasa (kriteria 1) & 3,33 & 83,33 \\
Bahasa (kriteria 2) & 3,67 & 91,67 \\
\hline Rata-rata & 3,5 & 87,5 \\
\hline
\end{tabular}

Visual grafik hasil dari validasi panduan oleh ahli materi yang dilakukan oleh beberapa dosen di beberapa perguruan tinggi sebagaimana pada gambar 4 .

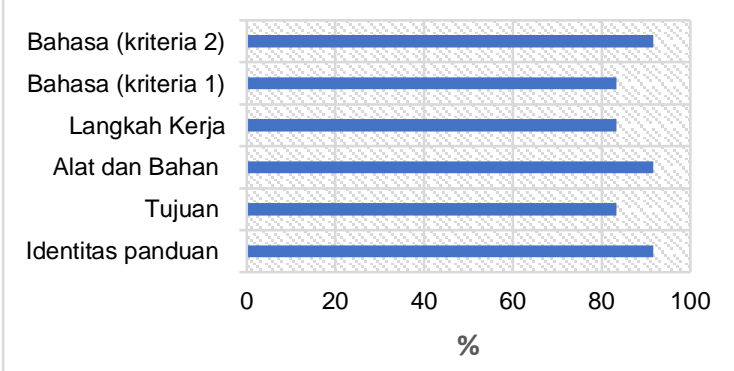

Gambar 4. Hasil validasi dari ahli materi

\section{PEMBAHASAN}

Ada beberapa perbedaan komponen penilaian antara ahli pengguna dengan ahli materi. Komponen ahli pengguna lebih kepada bagaimana kejelasan mereka setelah menggunakan panduan penggunaan. Sedangkan untuk komponen penilaian ahli materi lebih kepada bagaimana kesesuaian materi dan kelengkapan pada setiap kriteria pokok panduan eksperimen.

Dari hasil analisis diatas bahwa didapatkan nilai persentase sebesar 79,69\% untuk validasi pengguna yang artinya panduan masuk dalam kriteria baik. Dan hasil analisis dengan nilai $87,5 \%$ untuk validasi materi yang artinya masuk dalam kriteria sangat baik. Meskipun hasil penilaian dari ahli pengguna sudah dalam kriteria baik, perlu kiranya perbaikan-perbaikan sesuai dengan saransaran untuk kesempurnaan dari panduan eksperimen sehingga dapat digunakan dalam pembelajaran dengan kriteria sangat layak (Darmayanti \& Haifaturrahmah, 2019).

\section{PENUTUP}

Panduan video analisis pada materi kinematika telah selesai divalidasi oleh beberapa ahli. Diantaranya adalah ahli pengguna dalam hal ini mahasiswa, dan ahli materi dalam hal ini adalah dosen. Dari hasil analisis validasi oleh kedua ahli menghasilkan rata-rata panduan dalam kriteria baik. Sehingga dapat disimpulkan bahwa panduan video analisis pada materi mekanika ini layak untuk dapat digunakan oleh calon guru fisika.

\section{REFERENSI}

Darmayanti, N. W. S., \& Haifaturrahmah, H. (2019). Analisis Kelayakan Buku Panduan Praktikum Ipa Terpadu Smp Berpendekatan Saintifik Dengan Berorientasi Lingkungan Sekitar. ORBITA: Jurnal Kajian, Inovasi Dan Aplikasi Pendidikan Fisika, 5(1), 45-47. https://doi.org/10.31764/orbita.v5i1.1021

Ellis, T. J., \& Levy, Y. (2010). A Guide for Novice Researchers: Design and Development Research Methods. Proceedings of Informing Science \& IT Education Conference (InSITE), (10), 107-118. Retrieved from http://proceedings.informingscience.org/l nSITE2010/InSITE10p107118Ellis725.pdf

Firdaus, T., Setiawan, W., \& Hamidah, I. (2017). The Kinematic Learning Model using Video and Interfaces Analysis. Journal of Physics: Conference Series, 895,

012108. https://doi.org/10.1088/17426596/895/1/012108

Firdaus, T., \& Sinensis, A. R. (2017). Video Analisis untuk Kemampuan Menganalisis dan Memecahkan Masalah Materi Kinematika pada Calon Guru Fisika. Jurnal Penelitian Pembelajaran Fisika, 8(2), 135-142.

Lusiyana, A., Toifur, M., \& Rohman, F. (2012). Permeabilitas Relatif Menggunakan Logger Pro, 78-82.

Milner-Bolotin, M., \& Moll, R. (2008). Physics 
Exam Problems Reconsidered: Using Logger Pro to Evaluate Student Understanding of Physics. The Physics Teacher, 46(8), 494-500. https://doi.org/10.1119/1.2999067

Nursapikka, E., Daningsih, E., \& Yokhebed. (2017). Kelayakan Penuntun Praktikum pada Submateri Peran Tumbuhan di Bidang Ekonomi Kelas X SMA. Jurnal Pendidikan Dan Pembelajaran, 6(11), 110.

Peffers, K., Tuunanen, T., Rothenberger, M. A., \& Chatterjee, S. (2007). A Design Science Research Methodology for Information Systems Research. Journal of Management Information Systems, 24(3), 45-77. Retrieved from http://search.ebscohost.com/login.aspx?

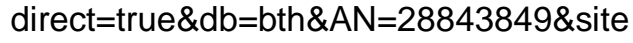
$=$ ehost-live \&scope $=$ site

Sahrir, M. S., Alias, N. A., Ismail, Z., \& Osman, N. (2012). Employing design and development research (DDR) approaches in the design and development of online arabic vocabulary learning games prototype. Turkish Online Journal of Educational Technology, 11(2), 108-119.

Suprianto, Kholida, S. I., \& Andi, H. J. A. (2017). Pengembangan Panduan Praktikum Fisika Dasar 1 Berbasis Guided Inquiry untuk Meningkatkan Kemampuan Hard Skill dan Soft Skill Mahasiswa (Calon Guru Fisika). In Seminar Nasional Hasil Penelitian Universitas Kanjuruhan Malang 2017 (Vol. 34, pp. 487-494). Malang. 